\title{
MEMACU PERTUMBUHAN EKONOMI DI PROPINSI JAWA TENGAH MELALUI PENINGKATAN KUNJUNGAN WISATAWAN DENGAN JUMLAH HOTEL DAN PENDAPATAN ASLI DAERAH SEBAGAI VARIABEL INTERVENING
}

\author{
Srisinto \\ srisinto@bps.go.id
}

\begin{abstract}
ABSTRAK
Tujuan penelitian ini untuk menganalisis pengaruh jumlah wisatawan terhadap pertumbuhan ekonomi dengan jumlah hotel dan pendapatan asli daerah (PAD) sebagai variabel antara atau intervening di Propinsi Jawa Tengah. Secara teori, jumlah wisatawan berpengaruh terhadap PAD melalui variabel jumlah hotel, sedangkan jumlah wisatawan dan jumlah hotel berpengaruh terhadap pertumbuhan ekonomi melalui PAD, untuk itu didalam penelitian ini digunakan metode analisis jalur (path analysis). Data yang digunakan dalam penelitian ini berasal dari Badan Pusat Statisik (BPS), yaitu jumlah wisatawan, jumlah hotel, pendapatan asli daerah (PAD) dan produk domestik regional bruto (PDRB) atas dasar harga konstan tahun 2010. Hasil penelitian menunjukan bahwa i) jumlah wisatawan dan jumlah hotel secara simultan berpengaruh positip dan signifikan terhadap pendapatan asli daerah (PAD) ii) jumlah wisatawan, jumlah hotel dan pendapatan asli daerah (PAD) secara simultan berpengaruh positip terhadap pertumbuhan ekonomi. Dengan mengacu hasil penelitian tersebut, serta untuk meningkatkan PAD di propinsi Jawa Tengah maka perlu upaya dari pemerintah setempat beserta stakeholder berusaha memperbaiki fasilitas serta sarana dan prasarana yang berkaitan dengan kegiatan kepariwisataan. Dalam penelitian ini variabel intervening berupa jumlah hotel, perlu dipertimbangkan sebagai usaha meningkatkan pendapatan asli daerah (PAD) di propinsi Jawa Tengah.
\end{abstract}

Kata Kunci : Jumlah wisatawan, jumal hotel, pendapatan asli daerah (PAD) dan pertumbuhan ekonomi.

\begin{abstract}
The purpose of this study was to analyze the effect of the number of tourists on economic growth with the number of hotels and local revenue (PAD) as intermediate or intervening variables in Central Java Province. In theory, the number of tourists influences PAD through the variable number of hotels, while the number of tourists and the number of hotels influences economic growth through PAD, for this reason the path analysis method is used in this study. The data used in this study came from the Central Statistics Agency (BPS), namely the number of tourists, the number of hotels, local revenue (PAD) and gross regional domestic product (GDP) on the basis of constant prices in 2010. The results showed that i) the amount tourists and the number of hotels simultaneously had a positive and significant effect on local revenue (PAD) ii) the number of tourists, the number of hotels and local revenue (PAD) simultaneously had a positive effect on economic growth. By referring to the results of these studies, as well as to increase PAD in Central Java province, efforts are needed from the local government and stakeholders to try to improve the facilities and facilities and infrastructure related to tourism activities. In this study the intervening variable in the form of the number of hotels, needs to be considered as an effort to increase local revenue (PAD) in the Central Java province.
\end{abstract}

Keywords: Number of tourists, Number of hotels, Regional Original Income (PAD) and Economic Growth.

\section{PENDAHULUAN Latar Belakang}

Produk Domestik Bruto pada tingkat nasional serta Produk Domestik Regional Bruto (PDRB) pada tingkat regional (provinsi) menggambarkan kemampuan suatu wilayah untuk menciptakan nilai tambah pada suatu waktu tertentu. Untuk menyusun PDB maupun
PDRB digunakan 2 (dua) pendekatan yaitu lapangan usaha dan pengeluaran. PDB maupun PDRB dari sisi lapangan usaha merupakan penjumlahan seluruh komponen nilai tambah bruto yang mampu diciptakan oleh sektor-sektor ekonomi atas berbagai aktivitas produksinya. Dan penggunaan dari nilai tambah dijelaskan dari sisi pengeluaran. 
Produk Domestik Regional Bruto maupun agregat turunannya disajikan dalam 2 (dua) versi penilaian, yaitu atas dasar "harga berlaku" dan atas dasar "harga konstan". Disebut sebagai harga berlaku karena seluruh agregat dinilai dengan menggunakan harga pada tahun berjalan, sedangkan harga konstan penilaiannya didasarkan kepada harga satu tahun dasar tertentu, dalam hal ini digunakan harga tahun 2010.

Laju pertumbuhan Produk Domestik Regional Bruto diperoleh dari perhitungan PDRB atas dasar harga konstan yaitu dengan mengurangi nilai PDRB pada tahun ke-n terhadap nilai pada tahun ke n-1 (tahun sebelumnya), dibagi dengan nilai pada tahun ke n-1, dikalikan dengan 100 persen.

Pertumbuhan ekonomi di Propinsi Jawa Tengah yang digambarkan dengan besaran angka produk domestik regional bruto (PDRB) harga konstan selalu mengalami kenaikan selama tujuh tahun terakhir. Tahun 2011 sebesar 656268129,91 meningkat menjadi 691343115,96 di tahun 2012. Kemudian terus meningkat sampai dengan tahun 2017 sebesar 894.050.472,53 sedangkan pertumbuhan tersebut ada pada kisaran 5\% (lima persen). Data lengkap tentang perkembangan produk domestik regional bruto (PDRB) harga konstan di Jawa Tengah dapat dilihat pada tabel 1 .

Tabel 1 Jumlah Wisatawan, jumlah hotel, PAD dan Pertumbuhan Ekonomi Di Propinsi Jawa Tengah Tahun 2010 - 2017

\begin{tabular}{|c|c|c|c|c|}
\hline Tahun & $\begin{array}{c}\text { Jumlah } \\
\text { Wisata }\end{array}$ & Jumlah Hotel & PAD & $\begin{array}{c}\text { Pertumbuhan } \\
\text { Ekonomi }\end{array}$ \\
\hline 2011 & 22219865 & 1368 & 50887132,12 & 656268129,91 \\
\hline 2012 & 25603157 & 1441 & 60440439,00 & 691343115,96 \\
\hline 2013 & 29818752 & 1463 & 75904605,72 & 726655118,06 \\
\hline 2014 & 30271679 & 1528 & 99163156,24 & 764959150,95 \\
\hline 2015 & 31807246 & 1533 & 10904882,00 & 806765092,17 \\
\hline 2016 & 37478700 & 1627 & 11541030,00 & 849313199,72 \\
\hline 2017 & 40899577 & 1958 & 12547513,00 & 894050472,53 \\
\hline
\end{tabular}

Sumber : Jawa Tengah Dalam Angka Tahun 2012-2018

Berlakunya otonomi daerah dapat dipastikan bahwa pemerintah daerah harus mampu meningkatkan Pendapatan Asli Daerah (PAD) semaksimal mungkin. Pendapatan Asli Daerah berasal dari hasil pajak daerah, hasil retribusi daerah, hasil kekayaan daerah yang telah dipisahkan, dan pemasukan lain yang berasal dari daerah yang sah yang bertujuan untuk memberikan kebebasan kepada setiap daerah dalam menggali pendanaan yang berasal dari daerah dalam melaksanakan suatu otonomi daerah sebagai perwujudan asas desentraisasi.

Pajak Hotel termasuk sebagai bagian dari PAD sebagai pajak daerah, sementara peningkatan pajak hotel salah satunya dipengaruhi oleh banyaknya tamu yang menginap di hotel tersebut. Salah satu faktor peningkatan jumlah tamu yang menginap didalam hotel adalah banyaknya wisatawan yang berkunjung ke wilayah tersebut. Hal tersebut sesuai dengan pendapat beberapa ahli berikut : Menurut (Manurung, 2013) Pendapatan Asli Daerah merupakan penerimaan daerah yang bersumber dari sektor pajak daerah, retribusi daerah, hasil purusahaan milik daerah, hasil pengelolaan kekayaan daerah yang dipisahkan, dan lain-lain pendapatan asli daerah yang sah. Pendapatan Asli Daerah seluruh pendapatan pajak maupun retribusi daerah yang termasuk sektor pariwisata (pajak meningkatkan pendapatan asli daerah dan pendapatan masyarakat pengelola obyek wisata (Rantetadung, 2012).

Jumlah wisatawan di propinsi Jawa Tengah dari tahun 2010 sampai tahun 2017 mengalami peningkatan. Tahun 2010 
sebesar 22.592.951 wisatawan meningkat menjadi 22219865 wisatawan pada tahun 2011. Kemudian terus meningkat sampai dengan tahun 2017 menjadi 40.899.577 wisatawan. Peningkatan jumlah wisatawan di propinsi Jawa Tengah tentunya akan berdampak pada peningkatan pendapatan asli daerah (PAD), dan seterusnya akan berimbas pada peningkatan pertumbuhan ekonomi.

\section{Perumusan Masalah}

Berdasarkan latar belakang yang telah diuraikan, maka dapat dikemukakan rumusan masalah sebagai berikut :

a. Apakah jumlah wisatawan berpengaruh terhadap jumlah hotel di Provinsi Jawa Tengah

b. Apakah jumlah wisatawan dan jumlah hotel secara individu berpengaruh terhadap pendapatan asli daerah (PAD) di Provinsi Jawa Tengah

c. Apakah jumlah wisatawan, jumlah hotel dan pendapatan asli daerah (PAD) secara individu berpengaruh terhadap pertumbuhan ekonomi di Provinsi Jawa Tengah

d. Apakah jumlah wisatawan, jumlah hotel dan pendapatan asli daerah (PAD) secara bersama-sama berpengaruh terhadap pertumbuhan ekonomi di Provinsi Jawa Tengah

\section{Tujuan Penelitian}

Tujuan penelitian adalah sebagai berikut:

a. Untuk mengetahui pengaruh individu dan bersama-sama antara jumlah wisatawan dan jumlah hotel terhadap pendapatan asli daerah (PAD) di Provinsi Jawa Tengah

b. Untuk mengetahui pengaruh individu atau parsial antara jumlah wisatawan, jumlah hotel dan pendapatan asli daerah (PAD) terhadap pertumbuhan ekonomi di Provinsi Jawa Tengah c. Untuk mengetahui pengaruh simultan (bersama-sama) antara jumlah wisatawan, jumlah hotel dan pendapatan asli daerah (PAD) terhadap pertumbuhan ekonomi di Provinsi Jawa Tengah

\section{KAJIAN PUSTAKA \\ Pertumbuhan Ekonomi}

Menurut Djoyohadikusumo (1994) dalam salmani (2013:31) memberikan batasan tentang pertumbuhan ekonomi yang ditandai dengan tiga ciri pokok, yaitu adanya laju pertumbuhan pendapatan perkapita dalam arti nyata (riil), persebaran (distribusi) angkatan kerja menurut sektor kegiatan yang menjadi sumber nafkah serta pola persebaran penduduk dalam masyarakat. (Djoyohadikusumo (1994) dalam (2013:31).

Pertumbuhan ekonomi didefinisikan sebagai penjelasan mengenai faktor-faktor apa yang menentukan kenaikan output per kapita dalam jangka panjang, dan penjelasan mengenai bagaimana faktorfaktor tersebut berinteraksi satu sama lain, sehingga terjadi proses pertumbuhan (Boediono,1999:10). Produk Domestik Bruto pada tingkat nasional serta Produk Domestik Regional Bruto (PDRB) pada tingkat regional (provinsi) menggambarkan kemampuan suatu wilayah untuk menciptakan nilai tambah pada suatu waktu tertentu. Untuk menyusun PDB maupun PDRB digunakan 2 pendekatan, yaitu lapangan usaha dan pengeluaran.

\section{Pendapatan Asli Daerah}

Menurut Yusuf (2001 : 24) pendapatan adalah aliran penerimaan kas atau harta lain yang diterima dari konsumen sebagai hasil penjualan barang atau pemberian jasa. Menurut Yani (2002 : 39), Pendapatan Asli Daerah adalah penerimaan yang diperoleh dari sumbersumber dalam wilayahnya sendiri yang dipungut berdasarkan peraturan daerah 
sesuai dengan peraturan perundangundangan. Menurut (Mardiasmo, 2002), pendapatan asli daerah adalah penerimaan yang diperoleh dari sector pajak daerah, retribusi daerah, hasil perusahaan milik daerah, hasil pengelolaan kekayaaan daerah yang dipisahkan, dan lain-lain pendapatan asli daerah yang sah. Menurut Ahmad dalam (Antari, 2013), Juga menyebutkan bahwa Pendapatan Asli Daerah adalah penerimaan yang diperoleh daerah dari sumber-sumber dalam wilayahnya sendiri yang dipungut berdasarkan peraturan perundangundangan yang berlaku.

\section{Wisatawan}

Pariwisata dalam bahasa inggrisnya "travel" yang berarti perjalanan yang dilakukan berkali-kali dari satu tempat ketempat lain. Pariwisata adalah sumber utama penggerak ekonomi di negara berkembang. Sektor pariwisata seperti ekowisata dan wisata pedesaan banyak yang di kunjungi wisatawan (Lacher dan Nepal : 2010). Kegiatan atau aktivitas pariwisata pada perkembangannya telah menjadi industri pariwisata dan merupakan salah satu industri yang dapat memberikan keuntungan secara ekonomi (Wibowo, 2012).

\section{Hotel}

Hotel adalah suatu usaha yang menggunakan suatu bangunan atau bagian dari bangunan dari padanya yang khusus disediakan, dimana setiap orang dapat menginap dan makan serta memperoleh pelayanan dan fasilitas lainnya dengan pembayaran (mempunyai restoran yang berada dibawah manajemen hotel tersebut). Sedangkan syarat hotel berbintang dalah harus memiliki : 1) fisik, meliputi lokasi, kondisi dan sebagainya. 2) bentuk pelayanan (service) 3) kualifikasi tenaga kerja, pendidikan dan kesejahteraan 4) fasilitas olah raga dan fasilitas lainnya 5) jumlah kamar yang tersedia

Gambar 1 Kerangka Pemikiran

\section{Kerangka Pemikiran}

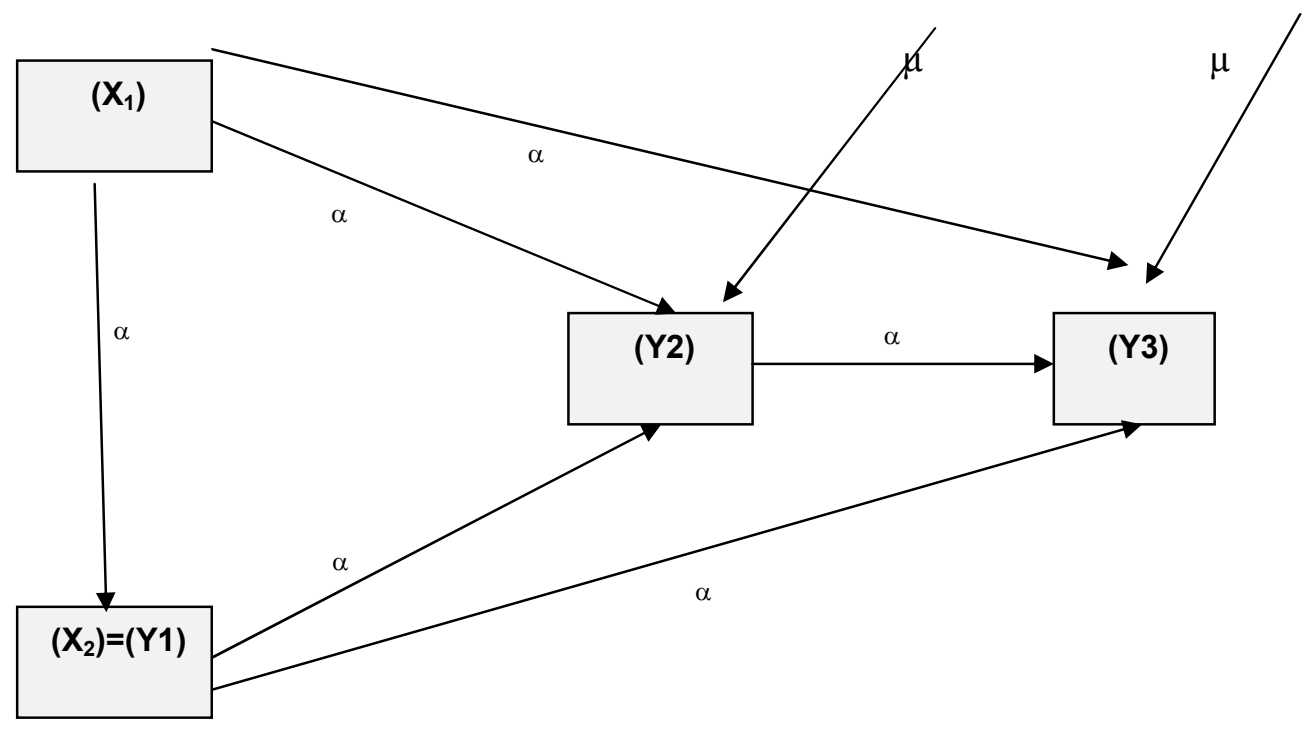

\section{Keterangan :}

$$
\begin{array}{cl}
\mathrm{X} 1 & =\text { Jumlah wisatawan } \\
\mathrm{X} 2 & =\mathrm{Y} 1=\text { Jumlah Hotel } \\
\mathrm{Y} 2 & =\text { Pendapatan Asli Daerah }
\end{array}
$$




$$
\begin{array}{ll}
\mathrm{Y} 3 & =\text { Pertumbuhan Ekonomi } \\
\mu & =\text { Error Term (residue) }
\end{array}
$$

Bentuk model sub-struktur 1 adalah :

$\mathrm{Y} 1=\mathrm{a}+\mathrm{PX} 2 \mathrm{X} 1$

Bentuk model sub-struktur 2 adalah :

$\mathrm{Y}_{2}=\mathrm{PY}_{2} \mathrm{X}_{1}+\mathrm{PY}_{2} \mathrm{X}_{2}+\mu_{2}$

Bentuk model sub-struktur 3 adalah :

$\mathrm{Y}_{2}=\mathrm{PY}_{3} \mathrm{X}_{1}+\mathrm{PY}_{3} \mathrm{X}_{2}+\mathrm{PY} 3 \mathrm{Y} 2+\mu 3$

\section{Hipotesis}

Hipotesis yang dirumuskan adalah sebagai berikut:

1. Jumlah wisatawan berpengaruh positip terhadap jumlah hotel di propinsi Jawa Tengah

2. Jumlah wisatawan dan jumla hotel secara individu atau parsial dan secara bersamasama tau simultan berpengaruh terhadap pendapatan asli daerah (PAD) di Provinsi Jawa Tengah

3. Jumlah wisatawan, jumlah hotel dan pendapatan daerah (PAD) secara individu atau parsial maupun bersama-sama atau simultan berpengaruh terhadap pertumbuhan ekonomi di Provinsi Jawa Tengah

\section{HASIL PENELITIAN DAN PEMBAHASAN Hasil Penelitian}

\section{Y1 = a + PX2X1 (Persamaan Substruktur 1)}

Tabel 2 Model Summary ${ }^{b}$

\begin{tabular}{|l|r|r|r|r|r|}
\hline Model & \multicolumn{1}{|c|}{$\mathrm{R}$} & R Square & $\begin{array}{c}\text { Adjusted R } \\
\text { Square }\end{array}$ & $\begin{array}{c}\text { Std. Error of the } \\
\text { Estimate }\end{array}$ & $\begin{array}{c}\text { Durbin- } \\
\text { Watson }\end{array}$ \\
\cline { 5 - 6 } & & & & & \\
\hline 1 &, $912^{\mathrm{a}}$ &, 831 &, 797 & 87,24772 & 1,927 \\
\hline
\end{tabular}

a. Predictors: (Constant), WISATA

b. Dependent Variable: jumlah_hotel

Tabel 3 ANOVA ${ }^{\mathrm{a}}$

\begin{tabular}{|rl|r|r|r|r|r|}
\hline \multicolumn{1}{|l|}{ Model } & \multicolumn{1}{|c|}{$\begin{array}{c}\text { Sum of } \\
\text { Squares }\end{array}$} & df & Mean Square & F & Sig. \\
\hline \multirow{2}{*}{1} & Regression & 187018,604 & 1 & 187018,604 & 24,568 &, $004^{\mathrm{b}}$ \\
& Residual & 38060,825 & 5 & 7612,165 & & \\
\hline & Total & 225079,429 & 6 & & & \\
\hline
\end{tabular}

a. Dependent Variable: jumlah_hotel

b. Predictors: (Constant), WISĀTA 
Tabel 4 Coefficients ${ }^{a}$

\begin{tabular}{|rc|r|r|r|r|r|}
\hline \multicolumn{2}{|l|}{ Model } & \multicolumn{2}{|c|}{ Unstandardized Coefficients } & \multicolumn{1}{|c|}{$\begin{array}{l}\text { Standardized } \\
\text { Coefficients }\end{array}$} & \multirow{2}{*}{ Sig. } \\
\cline { 3 - 5 } & & \multicolumn{1}{|c|}{$\mathrm{B}$} & Std. Error & \multicolumn{1}{c|}{ Beta } & & \\
\hline \multirow{2}{*}{1} & (Constant) & 705,139 & 175,535 & & 4,017 &, 010 \\
& WISATA &, 027 &, 006 &, 912 & 4,957 &, 004 \\
\hline
\end{tabular}

a. Dependent Variable: jumlah_hotel

\section{Pengaruh jumlah wisatawan terhadap jumlah hotel}

Untuk melihat pengaruh variabel jumlah wisatawan terhadap jumlah jumlah hotel, maka dilihat angka $\mathrm{R}$ square pada tabel 2 atau tabel model summary diatas. Besarnya angka $R$ square $\left(\mathrm{r}^{2}\right)$ adalah 0,831 atau 83,1 persen (persen), angka tersebut menunjukan besarnya pengaruh jumlah wisatawan terhadap jumlah hotel di propinsi Jawa Tengah. Angka tersebut mempunyai maksud bahwa besarnya pengaruh jumlah wisatawan terhadap jumlah hotel di propinsi Jawa tengah adalah sebesar 83,1 persen, sedangkan sisanya sebesar
$100 \%-83,1 \%=16,9 \%$ dipengaruhi faktor lain.

\section{Uji hipotesis}

H0 : Tidak ada hubungan linear antara jumlah wisatawan dengan jumlah hotel

H1 : Terdapat hubungan linear antara jumlah wisatawan denga jumlah hotel

Dari hasil perhitungan didapatkan angka signifikansi sebesar $0,004<0,05$, maka H0 ditolak dan H1 diterima, artinya ada hubungan linear antara jumlah wisatawan dengan jumlah hotel di propinsi Jawa Tengah.

\section{$\mathrm{Y}_{2}=\mathrm{PY} 2 \mathrm{X}_{1}+\mathrm{PY} 2 \mathrm{X}_{2}+\mu_{2}($ Persamaan Sub Struktur 2)}

Tabel 5 Model Summary ${ }^{b}$

\begin{tabular}{|l|r|r|r|r|r|}
\hline Model & R & R Square & $\begin{array}{c}\text { Adjusted R } \\
\text { Square }\end{array}$ & $\begin{array}{c}\text { Std. Error of the } \\
\text { Estimate }\end{array}$ & Durbin-Watson \\
\hline 1 &, $945^{\mathrm{a}}$ &, 892 &, 838 & 1154036,41608 & 1,830 \\
\hline
\end{tabular}

a. Predictors: (Constant), jumlah_hotel, WISATA

b. Dependent Variable: PAD

Tabel 6 ANOVA ${ }^{a}$

\begin{tabular}{|c|c|c|c|c|c|c|}
\hline Model & & Sum of Squares & $\mathrm{df}$ & Mean Square & $\mathrm{F}$ & Sig. \\
\hline \multirow{3}{*}{1} & $\begin{array}{l}\text { Regressio } \\
\mathrm{n}\end{array}$ & $\begin{array}{r}44148099976179,33 \\
6\end{array}$ & 2 & $\begin{array}{r}22074049988089,66 \\
8\end{array}$ & \multirow[t]{3}{*}{16,575} & \multirow[t]{3}{*}{, $012^{\mathrm{b}}$} \\
\hline & Residual & 5327200198530,232 & 4 & 1331800049632,558 & & \\
\hline & Total & $\begin{array}{r}49475300174709,57 \\
0\end{array}$ & 6 & & & \\
\hline
\end{tabular}

a. Dependent Variable: PAD

b. Predictors: (Constant), jumlah_hotel, WISATA 
Tabel 7 Coefficients ${ }^{\mathrm{a}}$

\begin{tabular}{|rl|r|r|r|r|r|}
\hline \multicolumn{2}{|l|}{ Model } & \multicolumn{2}{|c|}{ Unstandardized Coefficients } & $\begin{array}{c}\text { Standardized } \\
\text { Coefficients }\end{array}$ & \multirow{2}{*}{ Sig. } \\
\cline { 3 - 6 } & \multicolumn{1}{|c|}{$\mathrm{B}$} & \multicolumn{1}{|c|}{ Std. Error } & \multicolumn{1}{c|}{ Beta } & \\
\hline \multirow{2}{*}{1} & (Constant) & $-1759338,408$ & 4773816,058 & &,- 369 &, 731 \\
& WISATA &, 506 &, 178 & 1,134 & 2,843 &, 047 \\
& jumlah_hotel & $-3153,704$ & 5915,350 &,- 213 &,- 533 &, 622 \\
\hline
\end{tabular}

a. Dependent Variable: PAD

Pengaruh jumlah wisatawan dan jumlah hotel secara bersama-sama atau simultan terhadap pendapatan asli daerah (PAD)

Untuk melihat pengaruh variabel jumlah wisatawan dan jumlah jumlah hotel terhadap pendapatan asli daerah (PAD), maka dilihat angka $\mathrm{R}$ square pada tabel 5 atau tabel model summary diatas. Besarnya angka $\mathrm{R}$ square (r2) adalah 0,892 atau 89,2 persen (persen), angka tersebut menunjukan besarnya pengaruh jumlah wisatawan dan jumlah hotel terhadap pendapatan asli daerah (PAD) secara bersama-sama atau simultan sebesar 89,2 persen sedangkan sisanya sebesar $100 \%-89,2 \%=10,8 \%$ dipengaruhi faktor lain atau variabel lain di luar model ini.

\section{Uji hipotesis}

H0 : Tidak ada hubungan linear antara jumlah wisatawan dan jumlah hotel secara simultan terhadap pendapatan asli daerah (PAD)

H1 : Terdapat hubungan linear antara jumlah wisatawan dan jumlah hotel secara siultan terhadap pendapatan asli daerah (PAD)

Dari hasil perhitungan didapatkan angka signifikansi sebesar 0,012<0,05, maka H0 ditolak dan $\mathrm{H} 1$ diterima, artinya ada hubungan linear antara jumlah wisatawan dan jumlah hotel di propinsi Jawa Tengah secara gabungan atau simultan terhadap pendapatan asli daerah (PAD)

Pengaruh jumlah wisatawan dan jumlah hotel secara individu atau parsial terhadap pendapatan asli daerah (PAD)
Untuk melihat besarnya pengaruh variabel jumlah wisatawan dan jumlah hotel terhadap pendapatan asli daerah (PAD) secara sendiri-sendiri atau parsial digunakan uji $t$, sedang untuk melihat besarnya pengaruh digunakan angka beta atau standardized coeffecient (lihat tabel $7=$ tabel Coefficients).

Hubungan antara jumlah wisatawan terhadap pendapatan asli daerah (PAD)

Untuk melihat apakah ada hubungan linear antara jumlah wisatawan dan pendapatan asli daerah (PAD), dilakukan langkah sebagai berikut :

Pertama menentukan hipotesis

H0 : Tidak ada hubungan linear secara individual atau parsial antara jumlah wisatawan dan pendapatan asli daerah (PAD)

H1 : Terdapat hubungan linear secara individual atau parsial antara jumlah wisatawan dan pendapatan asli daerah (PAD)

Kedua membandingkan nilai signifikansi $(0,05)$

Hasil perhitungan menunjukan angka signifikansi $(\mathrm{sig}) .=0,047<0,05$, maka H0 ditolak dan H1 diterima. Artinya Terdapat hubungan linear secara individu atau parsial antara jumlah wisatawan dan pendapatan asli daerah (PAD). Besarnya pengaruh jumlah wisatawan terhadap pendapatan asli daerah (PAD) sebesar 0,506 atau 50,60\%, berarti pula bahwa bertambahnya jumlah wisatawan akan meningkatkan pendapatan asli daerah di propinsi Jawa Tengah.

Hubungan antara jumlah hotel terhadap pendapatan asli daerah (PAD)

Untuk melihat apakah ada hubungan linear antara jumlah hotel dan pendapatan asli 
daerah (PAD), dilakukan langkah sebagai berikut :

Pertama menentukan hipotesis

HO : Tidak ada hubungan linear secara individual atau parsial antara jumlah hotel dan pendapatan asli daerah (PAD)

H1 : Terdapat hubungan linear secara individual atau parsial antara jumlah hotel dan pendapatan asli daerah (PAD)

Kedua membandingkan nilai signifikansi $(0,05)$

$\mathrm{Y}_{2}=\mathrm{PY}_{1} \mathrm{X}_{1}+\mathrm{PY}_{3} \mathrm{X}_{2}+\mathrm{PY} 3 \mathrm{Y} 2+\mu 3($ Persamaan Sub-struktur 3)

Tabel 8 Model Summary ${ }^{\text {b }}$

\begin{tabular}{|l|r|r|r|r|r|}
\hline Model & \multicolumn{1}{|c|}{$\mathrm{R}$} & R Square & $\begin{array}{c}\text { Adjusted R } \\
\text { Square }\end{array}$ & $\begin{array}{c}\text { Std. Error of the } \\
\text { Estimate }\end{array}$ & Durbin-Watson \\
\hline 1 &, $997^{\mathrm{a}}$ &, 993 &, 986 & 10070443,89379 & 1,693 \\
\hline
\end{tabular}

a. Predictors: (Constant), PAD, jumlah_hotel, WISATA

b. Dependent Variable: PDRB

Tabel 9 ANOVA ${ }^{\mathrm{a}}$

\begin{tabular}{|l|r|r|r|r|r|}
\hline Model & Sum of Squares & Df & Mean Square & F & Sig. \\
\hline Regression & 43752506931911848,0 & 3 & 14584168977303948,0 & 143,80 & \multirow{2}{*}{$001^{\mathrm{b}}$} \\
1 Residual & 304241520653937,200 & 3 & 101413840217979,060 & & \\
Total & 44056748452565784,0 & & & & \\
\hline
\end{tabular}

a. Dependent Variable: PDRB

b. Predictors: (Constant), PAD, jumlah_hotel, WISATA

Tabel 10 Coefficients ${ }^{\mathrm{a}}$

\begin{tabular}{|c|c|c|c|c|c|}
\hline \multirow[t]{2}{*}{ Model } & \multicolumn{2}{|c|}{ Unstandardized Coefficients } & \multirow{2}{*}{$\begin{array}{c}\text { Standardized } \\
\text { Coefficients }\end{array}$} & \multirow[t]{2}{*}{$\mathrm{t}$} & \multirow[t]{2}{*}{ Sig. } \\
\hline & B & Std. Error & & & \\
\hline \multirow[t]{4}{*}{ (Constant) } & 387515434,931 & 42358996,317 & & 9,148 & 003 \\
\hline & 5,157 & 2,700 & 387 & 1,910 & , 152 \\
\hline & 52038,593 & 53421,524 &, 118 & ,974 & 402 \\
\hline & 15,461 & 4,363 &, 518 & 3,544 & ,038 \\
\hline
\end{tabular}

a. Dependent Variable: PDRB

b. Dependent Variable: PAD

Pengaruh jumlah wisatawan, jumlah hotel dan pendapatan asli daerah (PAD) secara bersama-sama atau simultan terhadap pertumbuhan ekonomi

Untuk melihat pengaruh variabel jumlah wisatawan, jumlah hotel dan pendapatan asli daerah (PAD) terhadap pertumbuhan ekonomi, maka dilihat angka $\mathrm{R}$ square pada tabel 8 atau tabel model summary diatas. Besarnya angka $\mathrm{R}$ square $\left(\mathrm{r}^{2}\right)$ adalah 0,993 atau 99,3 persen (persen), angka tersebut menunjukan besarnya pengaruh jumlah wisatawan, jumlah hotel dan pendapatan asli daerah (PAD) terhadap pertumbuhan ekonomi secara bersama-sama atau simultan sebesar 99,3 persen sedangkan sisanya sebesar $100 \%-99,3 \%=0,7 \%$ 
dipengaruhi faktor lain atau variabel lain di luar model ini.

\section{Uji hipotesis}

H0 : Tidak ada hubungan linear antara jumlah wisatawan, jumlah hotel dan pendapatan asli daerah (PAD) secara simultan terhadap pertumbuhan ekonomi

H1 : Terdapat hubungan linear antara jumlah wisatawan, jumlah hotel dan pendapatan asli daerah (PAD) secara simultan terhadap pertumbuhan ekonomi.

Dari hasil perhitungan didapatkan angka signifikansi sebesar $0,001<0,05$, maka $\mathrm{H} 0$ ditolak dan H1 diterima, artinya ada hubungan linear antara jumlah wisatawan, jumlah hotel dan pendapatan asli daerah (PAD) di propinsi Jawa Tengah secara gabungan atau simultan terhadap pertumbuhan ekonomi

Pengaruh jumlah wisatawan, jumlah hotel dan pendapatan asli daerah (PAD) secara individu atau parsial terhadap pertumbuhan ekonomi

Untuk melihat besarnya pengaruh variabel jumlah wisatawan, jumlah hotel dan pendapatan asli daerah (PAD) tehadap pertumbuhan ekonomi secara sendiri-sendiri atau parsial digunakan uji $t$, sedang untuk melihat besarnya pengaruh digunakan angka beta atau standardized coeffecient (lihat tabel $10=$ tabel Coefficients)

Hubungan antara jumlah wisatawan terhadap pertumbuhan ekonomi

Untuk melihat apakah ada hubungan linear antara jumlah wisatawan dan pertumbuhan ekonomi, dilakukan langkah sebagai berikut :

Pertama menentukan hipotesis

HO : Tidak ada hubungan linear secara individual atau parsial antara jumlah wisatawan dan pertumbuhan ekonomi

H1 : Terdapat hubungan linear secara individual atau parsial antara jumlah wisatawan dan pertumbuhan ekonomi

Kedua membandingkan nilai signifikansi $(0,05)$
Hasil perhitungan menunjukan angka signifikansi (sig). $=0,152>0,05$, maka $\mathrm{H} 0$ diterima dan H1 ditolak.. Artinya Tidak terdapat hubungan linear secara individu atau parsial antara jumlah wisatawan dan pertumbuhan ekonomi. Besarnya pengaruh jumlah wisatawan terhadap pertumbuhan ekonomi sebesar 0,387 atau $38,70 \%$ tetapi tdak signifikan. berarti pula bahwa bertambahnya jumlah wisatawan akan meningkatkan pendapatan asli daerah di propinsi Jawa Tengah.

\section{Hubungan antara jumlah hotel terhadap} pertumbuhan ekonomi

Untuk melihat apakah ada hubungan linear antara jumlah hotel dan pertumbuhan ekonomi, dilakukan langkah sebagai berikut :

Pertama menentukan hipotesis

H0 : Tidak ada hubungan linear secara individual atau parsial antara jumlah hotel dan pertumbuhan ekonomi

H1 : Terdapat hubungan linear secara individual atau parsial antara jumlah hotel dan pertumbuhan ekonomi

Kedua membandingkan nilai signifikansi $(0,05)$

Hasil perhitungan menunjukan angka signifikansi $(\mathrm{sig}) .=0,402>0,05$, maka $\mathrm{H} 0$ diterima dan H1 ditolak. Artinya Tidak terdapat hubungan linear secara individu atau parsial antara jumlah hotel dan pertumbuhan ekonomi. Besarnya pengaruh jumlah hotel terhadap pertumbuhan ekonomi sebesar 0,213 atau $-21,3 \%$, tetapi tidak signifikan. berarti pula bahwa bertambahnya jumlah wisatawan akan meningkatkan pendapatan asli daerah di propinsi Jawa Tengah.

Hubungan antara pendapatan asli daerah (PAD) terhadap pertumbuhan ekonomi Untuk melihat apakah ada hubungan linear antara pendapatan asli daerah (PAD) dan pertumbuhan ekonomi, dilakukan langkah sebagai berikut :

Pertama menentukan hipotesis

H0 : Tidak ada hubungan linear secara individual atau parsial antara pendapatan asli daerah (PAD) dan pertumbuhan ekonomi

H1 : Terdapat hubungan linear secara individual atau parsial antara pendapatan asli daerah (PAD) dan pertumbuhan ekonomi 
Kedua membandingkan nilai signifikansi $(0,05)$

Hasil perhitungan menunjukan angka signifikansi $(\mathrm{sig}) .=0,038<0,05$, maka $\mathrm{H} 0$ ditolak dan $\mathrm{H} 1$ diterima. Artinya terdapat hubungan linear secara individu atau parsial antara jumlah pendapatan asli daerah (PAD) dan pertumbuhan ekonomi. Besarnya pengaruh pendapatan asli daerah (PAD) terhadap pertumbuhan ekonomi sebesar 0,518 atau $51,8 \%$. berarti pula bahwa bertambahnya jumlah wisatawan akan meningkatkan pendapatan asli daerah di propinsi Jawa Tengah.

\section{Perhitungan Pengaruh}

\section{Gambar 2 Model Diagram Jalur dengan Nilai Koefisien Jalur}

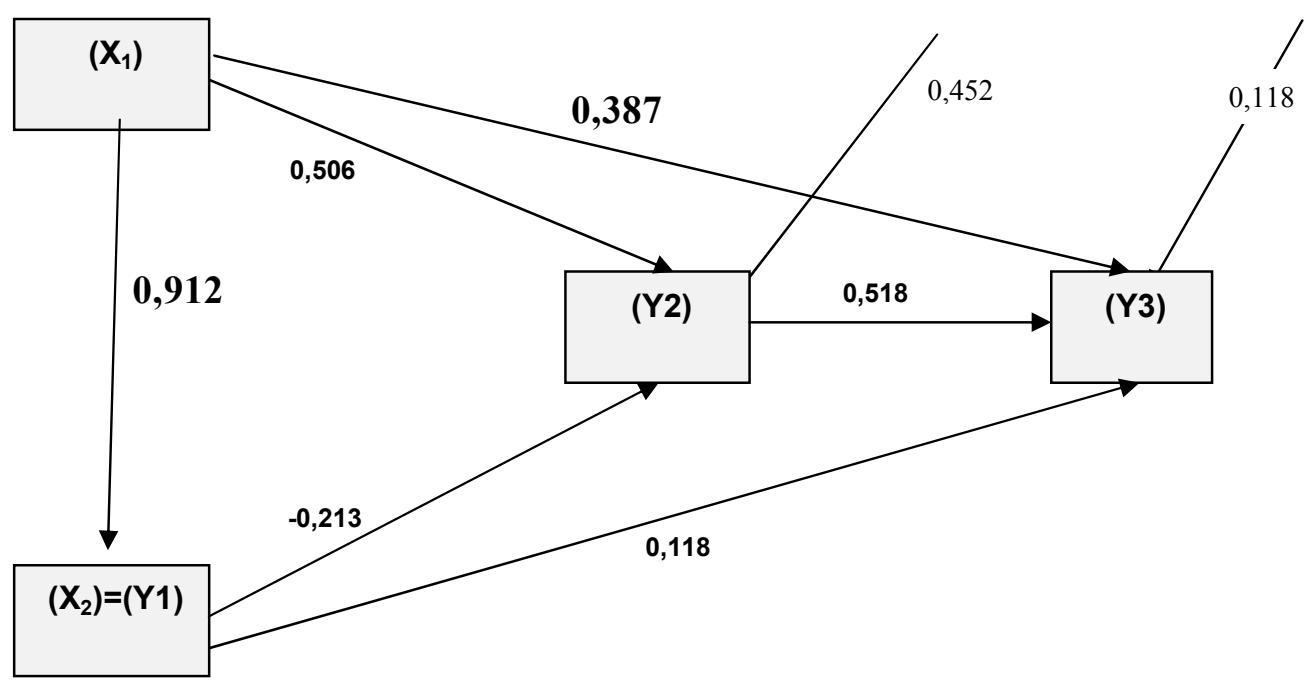

1. Pengaruh Langsung (direct effect)

a. Pengaruh jumlah wisatawan terhadap jumlah hotel $(\mathrm{X} 1 \rightarrow \mathrm{X} 2=0,912)$

b. Pengaruh jumlah wisatawan terhadap pendapatan asli daerah $(\mathrm{X} 1 \rightarrow \mathrm{Y} 2=0,506)$

c. Pengaruh jumlah hotel terhadap pendapatan asli daerah $(\mathrm{X} 2 \rightarrow \mathrm{Y} 2=-0,213)$

d. Pengaruh jumlas wisatawan terhadap pertumbuhan ekonomi $(\mathrm{X} 1 \rightarrow \mathrm{Y} 3=0,387)$

e. Pengaruh jumlah hotel terhadap pertumbuhan ekonomi $(\mathrm{X} 2 \rightarrow \mathrm{Y} 3=0,118)$

f. Pengaruh pendapatan asli daerah (PAD) terhadap pertumbuhan ekonomi $(\mathrm{Y} 2 \rightarrow \mathrm{Y} 3=$ $0,518)$

2. Pengaruh Tidak Langsung Langsung (indirect effect)

a. Pengaruh jumlah wisatawan terhadap pendapatan asli daerah (PAD) melalui jumlah hotel $\mathrm{X} 1 \rightarrow \mathrm{X} 2 \rightarrow \mathrm{Y} 2=(0,912 \mathrm{x}-0,213)=-0,194$

b. Pengaruh jumlah wisatawan terhadap pertumbuhan ekonomi melalui jumlah hotel $\mathrm{X} 1 \rightarrow$ $\mathrm{X} 2 \rightarrow \mathrm{Y} 3=(0,912 \times 0,118)=0,108$

c. Pengaruh jumlah wisatawan terhadap pertumbuhan ekonomi melalui pendapatan asli daerah $(\mathrm{PAD}) \mathrm{X} 1 \rightarrow \mathrm{Y} 2 \rightarrow \mathrm{Y} 3=(0,506 \times 0,518)=0,262$

d. Pengaruh jumlah hotel terhadap pertumbuhan ekonomi melalui pendapatan asli daerah $(\mathrm{PAD}) \mathrm{X} 2 \rightarrow \mathrm{Y} 2 \rightarrow \mathrm{Y} 3=(-0,213 \times 0,518)=-0,110$

3. Pengaruh Total (Total Effect)

a. Pengaruh jumlah wisatawan terhadap pendapatan asli daerah (PAD) melalui jumlah hotel $\mathrm{X} 1 \rightarrow \mathrm{X} 2 \rightarrow \mathrm{Y} 2=0,912-0,213=0,699$

b. Pengaruh jumlah wisatawan terhadap pertumbuhan ekonomi melalui jumlah hotel X1 $\rightarrow$ $\mathrm{X} 2 \rightarrow \mathrm{Y} 3=0,912+0,118=1,03$. 
c. Pengaruh jumlah wisatawan terhadap pertumbuhan ekonomi melalui pendapatan asli daerah $(\mathrm{PAD}) \mathrm{X} 1 \rightarrow \mathrm{Y} 2 \rightarrow \mathrm{Y} 3=0,506+0,518=1,024$

d. Pengaruh jumlah hotel terhadap pertumbuhan ekonomi melalui pendapatan asli daerah $(\mathrm{PAD}) \mathrm{X} 2 \rightarrow \mathrm{Y} 2 \rightarrow \mathrm{Y} 3=-0,213+0,518=0,305$

Tabel 11 Hasil Penghitungan Analisis Jalur (Path Analysis)

\begin{tabular}{|c|c|c|c|}
\hline Hubungan & $\begin{array}{c}\text { Pengaruh } \\
\text { Langsung }\end{array}$ & $\begin{array}{c}\text { Pengaruh Tidak } \\
\text { Langsung }\end{array}$ & Pengaruh Total \\
\hline $\mathrm{X} 1 \rightarrow \mathrm{X} 2$ & 0,912 & - & \\
\hline $\mathrm{X} 1 \rightarrow \mathrm{Y} 2$ & 0,506 & $-0,194$ & 0,699 \\
\hline $\mathrm{X} 1 \longrightarrow \mathrm{Y} 3$ & 0,387 & $0,108 / 0,262$ & $1,030 / 1,024$ \\
\hline $\mathrm{X} 2 \longrightarrow \mathrm{Y} 2$ & $-0,213$ & & 0,305 \\
\hline $\mathrm{X} 2 \longrightarrow \mathrm{Y} 3$ & 0,118 & $-0,110$ & \\
\hline $\mathrm{Y} 2 \longrightarrow \mathrm{Y} 3$ & 0,518 & & \\
\hline
\end{tabular}

Pembahasan

Pengaruh jumlah wisatawan terhadap jumlah hotel

Angka signifikansi sebesar $0,004<$ 0,05 , artinya $\mathrm{H} 0$ ditolak dan $\mathrm{H} 1$ diterima, jadi terdapat hubungan linear antara jumlah wisatawan dengan jumlah hotel di propinsi Jawa Tengah. Berarti pula semakin banyak jumlah wisatawan maka semakin banyak jumlah hotel di Jawa Tengah., atau dengan kata lain peningkatan jumlah wisatawan direspon positif para investor untuk mananamkan modal disubsektor perhotelan.

\section{Pengaruh jumlah wisatawan dan jumlah hotel terhadap PAD}

Angka signifikansi sebesar $0,012<$ 0,05 berarti secara bersama-sama atau simultan peningkatan jumlah wisatawan yang diikuti dengan peningkatan jumlah hotel akan meningkatkan PAD Propinsi Jawa Tengah. Namun jika pengaruh antara variabel jumlah wisatawan dan jumlah hotel terhadap pendapatan asli daerah (PAD) dilihat secara individual atau persial, maka hasilnya adalah sebagai berikut. Pengaruh jumlah wisatawan terhadap PAD adalah positif dan signifikan artinya semakin tinggi atau banyak wisatawan akan berimplikasi pada peningkatan PAD di Propinsi Jawa Tengah dan sebaliknya . Hal tersebut berbeda dengan penelitian yang dilakukan oleh I Kadek Budi Praga Swantara, Ida Bagus Darsana (2017), yang menyatakan bahwa kunjungan jumlah wisatawan tidak berpengaruh signifikan terhadap pendapatan asli daerah (PAD) di Kabupaten Gianjar, Bali. Tetapi sesuai dengan hasil penelitian yang dilakukan oleh Eko SatriadiPutra (2017) yang menyatakan bahwa jumlah wisatawan berpengaruh signifikan terhadap pendapatan asli daerah (PAD) di Kabupaten Pesisir Selatan.

Kemudian secara parsial pengaruh jumlah hotel terhadap PAD adalah negatif dan tidak signifikan. Hal tersebut menunjukkan bahwa peningkatan jumlah hotel akan mengakibatkan penurunan PAD di Jawa Tengah adalah tidak signifikan. Atau dengan kata lain peningkatan jumlah hotel akan diikuti dengan kanaikan PAD di Propinsi Jawa Tengah. Hal ini sesuai dengan hasil penelitian yang dilakukan oleh Rheza Prima Putra (2018) yang menyatakan bahwa jumlah hotel berpengaruh terhadap pendapatan asli daerah (PAD) di propinsi Bali.

\section{Pengaruh jumlah wisatawan, jumlah hotel dan PAD terhadap pertumbuhan ekonomi.}

Secara bersama-sama pengaruh jumlah wisatawan, jumlah hotel dan pendapatan asli daerah (PAD) terhadap pertumbuhan ekonomi adalah positip dan signifikan, hal ini ditunjukan dengan nilai signfikansi (sig $0,001<0,05)$, namun hal tersebut berbeda apabila pengaruh masing-masing variabel dilihat secara parsial atau individu.

Hasil penghitungan mengindikasikan bahwa pengaruh jumlah wisatawan terhadap pertumbuhan ekonomi adalah tidak 
signifikan (sig. 0,152 > 0,05) artinya bahwa kenaikan jumlah wisatawan secara individu atau parsial tidak signifikan mengakibatkan kenaikan pertumbuhan ekonomi di Propinsi Jawa Tengah. Hal ini berbeda dengan hasil penelitian terdahulu oleh Shakhibul Amnar, Said Muhammad, Mohd. Nur Syechalad Begitu juga untuk pengaruh jumlah hotel terhadap pertumbuhan ekonomi menunjukkan nilai signifikansi (sig. 0,402 > $0,05)$, berarti kenaikan jumlah hotel secara individu atau parsial tidak secara signifikan diikuti dengan peningkatan pertumbuhan ekonomi di Propinsi Jawa Tengah.

Sementara untuk pengaruh PAD terhadap pertumbuhan ekonomi hasilnya adalah signifikansi dengan nilai signifikansi sebesar (sig. 0,038<0,05). Berarti bahwa peningkatan PAD akan diikuti dengan peningkatan Pertumbuhan Ekonomi di Propoinsi Jawa Tengah. Hal ini sesuai dengan hasil penelitian yang dilakukan oleh Agung Priambo (2015) yang menyatakan bahwa pendapatan asli daerah (PAD) berpengaruh positip terhadap pertumbuhan ekonomi. Namun berbeda dengan hasil penelitian dewi Chrisanty Paat, Rosalina A.M. Koleangan, Vekie Adolf Rumate (2017), dimana hasil penelitiannya menunjukan bahwa pendapatan asli daerah (PAD) berpengaruh negatif terhadap pertumbuhan ekonomi akan tetapi tidak berpengaruh secara signifikan.

\section{Kesimpulan}

1. Jumlah wisatawan memiliki pengaruh positip dan signifikan terhadap jumlah hotel di propinsi Jawa Tengah.

2. Jumlah wisatawan dan jumlah hotel secara simultan atau bersama-sama memiliki pengaruh signifikan terhadap pendapatan asli daerah (PAD) di propinsi Jawa Tengah

3. Jumlah wisatawan secara individu atau parsial memiliki pengaruh positip yang tidak signifikan terhadap pendapatan asli daerah (PAD) di propinsi Jawa Tengah

4. Jumlah hotel secara individu atau parsial memiliki pengaruh negatip dan tidak signifikan terhadap
(2017), yang menyatakan bahwa 1) jumlah kunjungan wisatawan mancanegara berpengaruh positip dan signifikan terhadap pertumbuhan ekonomi regional kota Sabang. 2) Wisatawan nusantara mempunyai pengaruh positip dan signifikan terhadap pertumbuhan ekonomi regional kota Sabang. pendapatan asli daerah (PAD) di propinsi Jawa Tengah

5. Jumlah wisatawan, jumlah hotel dan pendapatan asli daerah (PAD) secara simultan atau bersama-sama memiliki pengaruh signifikan terhadap pertumbuhan ekonomi di propinsi Jawa Tengah

6. Jumlah wisatawan secara individu atau parsial memiliki pengaruh positip dan signifikan terhadap pertumbuhan ekonomi di propinsi Jawa Tengah

7. Jumlah hotel secara individu atau parsial memiliki pengaruh positip dan signifikan terhadap pertumbuhan ekonomi di propinsi Jawa Tengah

8. Jumlah pendapatan asli daerah (PAD) secara individu atau parsial memiliki pengaruh positip dan signifikan terhadap pertumbuhan ekonomi di propinsi Jawa Tengah

\section{DAFTAR PUSTAKA}

Antari,N.L.S.2013. Peran Industri Pariwisata Terhadap Penerimaan Pendapatan Asli Daerah Kabupaten Gianyar. Jurnal Perhotelan dan Periwisata.3(1).3545.http://doi.org/10.1017/CB 09781107415324.004

Boediono.1999. Teori Pertumbuhan Ekonomi. BPFE. UGM. Ygyakarta.

Djojohadikusumo. 1994 dalam Salmani. 2013. Shariah Ethical Invesment Products in Indonesian CapitMarket : The Debetes on their Integration Process in the Transitional Stage. In. Sharia Economics coverence. Hannover. German.

Lacher, R. Geoffrey \& Nepal,Sanjay.K. 2010. From Leakages to Linkages: local - Level Strategies for Capturing Tourism Revenue in Nortern Thailand. Clemson University. Bulletin of Indonesian Economic Studies. Pages 77-99. 


\begin{tabular}{cc}
\hline \hline Manurung,E.T. 2013. Perbandingan & Rangka Meningkatkan Ekonomi \\
Kontribusi Pariwisata Dalam & Masyarakat Kabupaten Bandung. Dalam \\
Meningkatkan Pendapatan Asli daerah & Jurnal Kepariwisataan Indonesia, 7 (2), \\
di Kabupaten bandung dan Buleleng & h : 563-573. \\
Periode 2010 - 2013. E-Journal Bisma & Yani, Ahmad. 2002. Hubungan Keuangan \\
Universitas Pendidikan Ganesha. & Antara Pemerintah Pusat dan Daerah di \\
Jurusan manajemen,3 (1). & Indonesia. PT. Rajagratindo. Jakarta. \\
Mardiasmo. 2002. Otonomi dan Manajemen & Yusuf, Haryono. 2001. Dasar-Dasar \\
Keuangan Daerah. & Akuntansi : Edisi Ke-5. Bagian Penerbit \\
Wibowo, Sukarno. 2012. Kondisi dan & STIE YKPN. Yogyakarta \\
Pengembangan Pariwisata Dalam &
\end{tabular}

